\title{
Внутрішньокісткове судинне утворення як причина тяжкої спонтанної кровотечі
}

\author{
С. В. Коломієць, В. І. Шинкевич
}

Українська медична стоматологічна академія, м. Полтава

\section{Intraosseal vascular tumor as a cause of spontaneous hemorrhage}

\author{
S. V. Kolomiiets, V. I. Shynkevych \\ Ukrainian Medical Stomatological Academy, Poltava
}

Кровотечу в порожнині рота часто спричиняють стоматологічні втручання. Окрім фізіологічних зрушень у системі гемостазу, супутню соматичну патологію, прийом медикаментів вважають факторами ризику виникнення такої кровотечі. Наявність недіагностованих, а отже, нелікованих захворювань крові, таких як лейкемія, тромбоцитопенія та гемофілія, $є$ імовірною причиною спонтанної кровотечі в порожнині рота, так само як і гіперваскулярні утворення, які в порожнині рота пов'язані з басейном сонних артерій. Окремим прикладом такого утворення, діагностика і лікування якого може бути справжнім викликом, $€$ внутрішньокісткові судинні аномалії щелеп.

Нами проаналізовано клінічне спостереження спонтанної кровотечі в порожнині рота з наданням догоспітальної допомоги в амбулаторних умовах. Для аналізу використано наукометричні бази даних PubMed i Google Scholar, пошук в яких здійснено за ключовими словами. Дизайн дослідження випадок-контроль, опис серій клінічних спостережень, оглядові статті та посібники включені в короткий огляд.

Зважаючи на невідкладний стан пацієнта, автори не отримували письмової інформованої згоди на використання матеріалів історії хвороби для статті, але їх висвітлення важливе для здобуття досвіду і мета-аналізу. У відповідності до Етичних стандартів правового регулювання відносин у публікації не розголошуються дані, які могли б сприяти встановленню особистості пацієнта.

Пацієнт А., 17 років, звернувся до амбулаторної хірургії зі скаргами на рухомість зуба на нижній щелепі зліва та спонтанні нічні кровотечі з рота, які проявляються бульканням і хрипами, що будить батьків, які, бачачи подушку в згустках крові, будять сина, а він потім блює кров'ю темного кольору. Останні два тижні ситуація повторювалася щоночі близько 4-ї години. Пацієнт не був обстежений на момент звернення, мав лише прицільний рентгенівський знімок першого нижнього лівого моляра (підозрюваного), виконаний за направленням від стоматолога, у якого перебував на диспансерному обліку з приводу кровоточивості ясен. Захворювання пародонту мали всі члени сім'ї, яке проявлялося кровоточивістю ясен, однак ніколи саме так, як у пацієнта А., що було з'ясовано зі слів матері. Інших скарг не було.

На рентгенівському знімку встановлена резорбція кісткової тканини у вигляді чіткої лінії $2-3$ мм навколо всіх коренів зуба з чіткими межами. Коронка зуба інтактна.
Об'єктивно підозрюваний зуб рухомий і піднятий над рівнем оклюзійної площини на кілька міліметрів, перкусія та пальпація зуба безболісні, перехідна складка в проекції коренів синюшного кольору, без нориць та рубців, безболісна. Ясна з ознаками запалення уздовж міжзубних сосочків і ясенного краю. Явної рецесії/гіпертрофії ясен немає. Глибинних вимірювань, пробу на кровоточивість не проводили.

Імовірні діагнози на даному етапі обстеження: одонтогенний запальний процес у поєднанні з порушенням системи згортання крові; пародонтальний синдром, пов'язаний з гематологічними захворюваннями; онкологічні захворювання, які могли зруйнувати судини.

Під час огляду у пацієнта почалася тяжка профузна кровотеча з рота (кількість втраченої крові становила близько трьох медичних ниркоподібних лотків), джерело якої було виявлено в міжзубному проміжку між першим (підозрюваним) і другим нижніми лівими молярами. Кровотечу вдалося зупинити шляхом тампонування стрічкою гемостатика альвостаз (близько 40 см!), який легко занурювався в міжзубний проміжок уздовж коренів першого моляра, в поєднанні з ін'єкцією дицинону і холодним компресом.

Пацієнт був госпіталізований до відділення щелепнолицевої хірургії, після консиліуму судинні хірурги виконали ангіографію (див. рисунок) і встановили діагноз «внутрішньокісткова гемангіома тіла нижньої щелепи».

3 огляду на неможливість перев'язки сонної артерії, пацієнта транспортували до національного центру, де йому
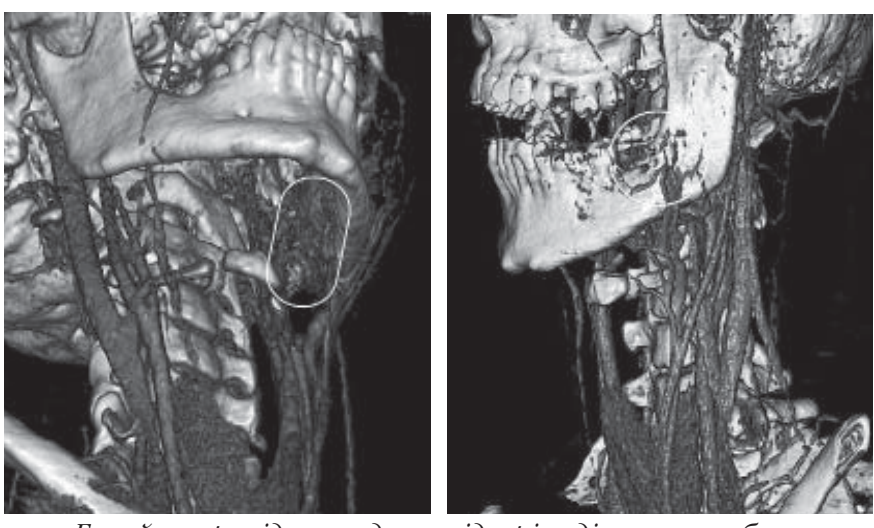

Басейни привідних судин у підозрілу ділянку, яка була джерелом кровотечі (позначено білими контурами): велика кількість судин з внутрішнъої (А) та зовнішнъої (Б) поверхонь лівого відділу нижнъої щелепи. 
виконали емболізацію привідних судин гемангіоми з видаленням першого лівого моляра як попередній етап до резекції нижньої щелепи з аутотрансплантаційним заміщенням. Подальший зв'язок з пацієнтом було перервано. Прогноз - пожиттєве спостереження через високий ризик виникнення рецидиву і загрозу спонтанної кровотечі [1].

Спостереження з детальним аналізом клінічних проявів, діагностики, патогістології і лікування внутрішньокісткових гемангіом та/або судинних мальформацій наведені в науковій літературі. Різноманітність клінічних проявів судинних утворень зумовила появу великої кількості термінів, але відповідно до класифікації спеціалістів серед судинних аномалій виділяють пухлини (понад 10 видів) і мальформації (8 видів) [2]. Для стоматолога рівень ознайомлення з судинною патологією обмежений гемангіомами, диференціальна діагностика яких із судинними мальформаціями мало базується на клінічних та рентгенологічних знахідках, в той час як невідкладна допомога та клінічний маршрут пацієнта мають ключове значення.

Гемангіоми щелеп є рідкісними і становлять менше 1\% серед кісткових ангіом (частіше локалізуються у хребті та довгих кістках, з незначною перевагою у жінок), мають тенденцію до виникнення у віці до 30 років, у той час як ураження інших кісток відбувається у старшому віці [3]. Спонтанна кровотеча у порожнині рота $є$ поширеним симптомом за наявності гемангіоми нижньої щелепи $[4,5]$. Артеріовенозні мальформації з високою швидкістю кровотоку найбільш агресивні та можуть спричинити смерть [6], тому потребують негайного лікування [1]. Венозні мальформації найбільш поширені, вони доброякісні, у близько 40\% хворих з'являються на голові та шиї і також загрожують виникненням спонтанної кровотечі [7].

Наведене клінічне спостереження - це класичний приклад судинної аномалії нижньої щелепи, яку можливо припустити на етапі збору скарг. Можливі інші клінічні прояви (поява рухомості зубів, зміна їх положення, відчуття пульсації в тканинах щелепи, деформація щелепи у вигляді ії вибухання), а також випадкові рентгенологічні знахідки, три з яких встановлені в даному клінічному спостереженні.

Клінічна та рентгенографічна діагностика гемангіом щелеп може бути складною внаслідок різноманітних проявів патології [3]. Ангіографія доцільна, коли необхідна емболізація гілок зовнішньої сонної артерії [8], що було обрано для пацієнта.

Лікування судинних аномалій полягає в комбінації склерозуючої, лазерної технік з хірургічними методами [7]. При артеріовенозних мальформаціях з високою швидкістю кровотоку нижньої щелепи виконують ендоваскулярну емболізацію, резекцію або їх комбінують. Проте рецидив нижньощелепних артеріовенозних мальформацій завжди є викликом для хірургів та інтервенційних радіологів, тому потрібне пожиттєве спостереження [1]. Емболізацію привідних судин з наступною екскохлеацією пухлини визнають як ефективне лікування з досить давніх часів [9]. У наведеному спостереженні госпітальне лікування було розпочато за стандартними принципами.

Клінічне спостереження не включає патогістологічне дослідження операційного матеріалу, тому діагноз верифіковано за даними ангіографічного дослідження як «внутрішньокісткова гемангіома тіла нижньої щелепи». Хірургічне лікування не гарантує відсутність рецидивів, які виникають часто та неодноразово.

Подібний пацієнт міг звернутися на прийом до стоматолога будь-якої спеціальності. Коли немає даних про захворювання крові, а спроби зупинити стійку кровотечу в амбулаторних умовах безуспішні, пацієнта транспортують до відділення щелепно-лицевої хірургії, де команда спеціалістів проводить необхідне обстеження та лікування. У наведеному спостереженні продемонстровано оптимальні алгоритм зупинки кровотечі та клінічний маршрут пацієнта. Додатково слід зауважити, що невидалений зуб відіграв важливу роль, завдяки йому притискали судини гемангіоми під час транспортування пацієнта.

Прагматичний підхід на етапі амбулаторного прийому передбачає знання причин загрозливої для життя кровотечі. Крім гематологічних хвороб, спонтанну кровотечу в порожнині рота, можуть спричинити судинні аномалії, які у разі невізуалізованого джерела призводять до ураження щелеп.

\section{References}

1. Yeh C, Wu Y, Chen Y, Wong H. Contralateral De Novo Intraosseous Arteriovenous Malformation in a Child with Arteriovenous Malformation of Mandible Treated by Endovascular Embolotherapy. Interventional Neuroradiology. 2012 Dec;18(4):484-9.doi. org/10.1177/159101991201800415.

2. Wassef M, Blei F, Adams D, Alomari A, Baselga E, Berenstein A, et al. Vascular Anomalies Classification: Recommendations From the International Society for the Study of Vascular Anomalies. Pediatrics. 2015 Jul;136(1):e203-14. doi: 10.1542/peds.2014-3673.

3. Chandra SR, Chen E, Cousin T, Oda D. A case series of intraosseous hemangioma of the jaws: Various presentations of a rare entity. J Clin Exp Dent. 2017 Nov;9(11): e1366-e70. doi: 10.4317/jced.54285.

4. Puneet, Khanna R, Khanna AK, Kumar M. Haemangioma of the mandible. Indian Journal of Otolaryngology and Head \& Neck Surgery. 2004 Apr;56(2):159-60. doi:10.1007/BF02974329.

5. Dubois J, Garel L. Imaging and therapeutic approach of hemangiomas and vascular malformations in the pediatric age group. Pediatr Radiol. 1999 Nov;29:879-93. doi:10.1007/s002470050718.

6. Kaderbhai J, Breik O, Heggie AA, Penington AJ. High-flow paediatric mandibular arteriovenous malformations: case reports and a review of current management. International Journal of Oral and Maxillofacial Surgery. 2017 Dec;46(12):1650-5. doi:10.1016/j.ijom.2017.06.011.

7. Zheng JW, Mai HM, Zhang L, Wang YA, Fan XD, Su LX, et al. Guidelines for the treatment of head and neck venous malformations. Int J Clin Exp Med. 2013 May 22;6(5):377-89. PMID: 23724158.

8. Roginsky VV, Nadtochy AG, Grigorian AS, Sokolov YuYu, Soldatsky YuL, Koviazin VA, Paltova SYu. Diagnostics of formations from blood vessels at maxillofacial area and the neck of children. Stomatologiya detskogo vozrasta i profilaktika. 2010:9(1):56-61. [In Russian].

9. Yeoman CM. Management of Haemangioma involwing facial mandibular and pharyngeal structures. Br J Oral Maxillofac Surg. 1987 Jun;25(3):195-203. PMID: 3474017. 